\title{
Assessment of Peripheral Blood Smear Preparation Technique in Laboratories with High Sample Load
}

\author{
Sumanashree Mallappa*, Sachin Kolte, Nimisha Sharma, Arti Khatri and Indrani Dhawan \\ VMMC \& Safdarjung Hospital, New Delhi, India
}

\begin{abstract}
Background: Examination of the blood film is an important part of the hematological evaluation. The reliability of the information obtained depends heavily on well-made and well-stained films that are systematically examined. Commonly used method of smear preparation in hematology the wedge method. In wedge method two slides are used one slide is placed on a flat surface with all necessary conditions maintained and the other slide is used as a spreader slide with is used to spread the blood film producing a good tongue shaped smear.

In laboratory settings with high case load, same spreader is used to produce blood smears of multiple patients.

Methods: The study was designed to know if there is any carry over of cells if the same spreader is used to make blood smears of multiple patients in laboratories having high patient load.

Same spreader was used to make multiple smears from pancytopenia sample after using it initially to make smears from samples of leukemia and neutrophilic leucocytosis.

Result: Slides were examined and results were tabulated, which showed that there was a definite carry over of cells from one smear to another if the same spreader is used consequetively for multiple patients

Conclusion: Caution need to be used in laboratories with high case load where multiple smears need to be prepared and time constraint is a limiting factor. Use of advanced coulters can help in correlation of cells counts and typing instead of only depending on smears for cells counts and reporting. Collecting clinical details of the patient is an important step which is indispensable
\end{abstract}

Keywords: Peripheral Smear, High Case Load, Carry Over Of Cells

\section{Introduction}

Examination of the blood film is an important part of the hematological evaluation. ${ }^{1}$ Initiation of a PBF is often a clinical request by the attending clinician on account of a clinical suspicion or less frequently initiated by the laboratory ${ }^{2}$. The reliability of the information obtained depends heavily on well-made and well-stained films that are systematically examined. ${ }^{1}$

The method of making the films are : The two-slide or wedge method, the cover glass method, and the spinner method. Commonly used method of smear preparation in hematology the wedge method. In wedge method two slides are used one slide is placed on a flat surface with all necessary conditions maintained and the other slide is used as a spreader slide with is used to spread the blood film producing a good tongue shaped smear. ${ }^{1}$

In laboratory settings with high sample load, same spreader is used to prepare peripheral blood smears of multiple patients. Automation in smear preparation done by few hemoslider also uses the same technique of smearing but the spreader blade is cleaned each time before making the next smear. ${ }^{3}$
The speed and quality of information have become essential items in the release of laboratory reports ${ }^{4}$ Among the numerous advantages of using automated equipment are the reduce time to release results, high sensitivity, greater accuracy with reduced coefficient of variation, better reproducibility and higher productivity in laboratory testing ${ }^{5,6}$. Due to economic constraints faced by developing countries majority of the labs cannot go for automated slide makers and stainers, requiring strict quality controls and rechecks in manual techniques employed in smear preparation and staining.

So, the study was planned to know if there is any carry over of cells if the same spreader is used to make blood smears of multiple patients in laboratories having high patient load.

\section{Materials and Methods:}

One sample was taken each of - 1) Pancytopenia, 2) Leukemia and 3) Neutrophilic leucocytosis

Study was done to see if the use of same spreader used initially for leukemia and later for pancytopenia leads to any changes in TLC and PS findings of the pancytopenia case. 
Likewise it was also studied whether the use of same spreader initially for leucocytosis and later for pancytopenia led to any changes in TLC and PS findings of the latter case.

\section{Study was Divided into two Parts-}

1 A) One smear was prepared with leukemia sample initially and 6 successive smears were prepared with pancytopenia case using the same spreader, and B) One smear was prepared with neutrophilic leucocytosis sample initially and 6 successive smears were prepared with pancytopenia case using the same spreader

2 A) One smear was prepared with leukemia sample initially and one smear from pancytopenia sample using the same spreader and this step was repeated 6 times, and B) One smear was prepared with neutrophilic leucocytosis sample initially and one smear from pancytopenia with the same spreader and this step was repeated 6 times.

\section{Result}

One sample was taken each of - 1) Pancytopenia, 2) Leukemia and 3) Neutrophilic leucocytosis, With values as follows - (table1)

After the study results were tabulated and analysed (Table-2,3,4 and 5).

\section{Discussion:}

In the first part of study (Table 2 and 3)-

1. A) By the use of same spreader TLC was raised in the smears made from pancytopenia case. TLC was high in smear numbered L1 and L2, L3 smear also showed a raised TLC with respect to the pancytopenia case. And there was not so significant raise of TLC in smears which came later in the order namely L4 and L5.

There was a definite carry over of blast cells into successive smears in case of L1 and L2 smears and the blast cells were present with high $\mathrm{N} / \mathrm{C}$ ratio, scant agranular cytoplasm, indented nuclear membrane and inconscpicuous nucleoli. In smears numbered L3 and L4 there were cells with poorly maintained features which could not be clearly typed as blasts and smear L5 showed no blasts.
Irregular distribution of cells were seen predominantly in the head region of the smear (Table2)

B) TLC was also raised when successive smears were prepared from pancytopenia case using the same spreader used for leucoerythroblastic reaction casev(Table 3 ).

TLC was significantly raised in N1 Smear, TLC was also raised in N2 and N3 case with respect to the pancytopenia case and TLC raise was not so significant in N4 and N5 cases.

Cells were distributed irregularly mainly in tail end and margins of the smear and predominant population of cells constituted of mature neutrophils, band forms and few neutrophilic precursors. Smear N1 and N2 also showed Nucleated RBCs.

2) Second part of the study includes 5 sets of smears (table 4 and 5).

A) Same spreader used for making a leukemia smear was used to make one pancytopenia smear and the steps were repeated 5 times. There was a definite carry over of cells in almost all pancytopenia smears. TLC was significantly raised in almost all cases. Blast cells were positive in all the smears. There was irregular distribution of cells predominantly in head and in margins in few smears (Table 4)

B) Same spreader used for making a leucoerythroblastic smear was used to make one pancytopenia smear and the steps were repeated 5 times. There was a definite carry over of cells in almost all pancytopenia smears. TLC was significantly raised in almost all cases. Predominant population of cells constituted of neutrophils, band forms and shift to left cells. There was irregular distribution of cells predominantly in tail end and in margins (Table 5)

It was seen from the tabulation that there was clear carry over of the cells from the leukemia case and leucoerythroblastic reaction case to the subsequent smears if the same spreader is used.

Table 1:

\begin{tabular}{|l|l|l|l|}
\hline Case & Pancytopenia & Leukemia & Neutrophilic leucocytosis \\
\hline $\mathrm{RBC}$ & $2.01 \mathrm{million} / \mathrm{mm} 3$ & $1.99 \mathrm{million} / \mathrm{mm} 3$ & $2.66 \mathrm{million} / \mathrm{mm} 3$ \\
\hline $\mathrm{Hb}$ & $6.1 \mathrm{~g} / \mathrm{dl}$ & $5.3 \mathrm{~g} / \mathrm{dl}$ & $8.6 \mathrm{~g} / \mathrm{dl}$ \\
\hline $\mathrm{HCT}$ & $18.1 \%$ & $18.0 \%$ & $26.6 \%$ \\
\hline
\end{tabular}




\begin{tabular}{|c|c|c|c|}
\hline Case & Pancytopenia & Leukemia & Neutrophilic leucocytosis \\
\hline MCV & $90 f l$ & $91 \mathrm{~mm} 3$ & $100 / \mathrm{mm} 3$ \\
\hline $\mathrm{MCH}$ & $30.4 \mathrm{pg}$ & $26.8 p g$ & $32.2 \mathrm{pg}$ \\
\hline $\mathrm{MCHC}$ & $33.9 \mathrm{~g} / \mathrm{dl}$ & $29.6 \mathrm{~g} / \mathrm{dl}$ & $32.2 \mathrm{~g} / \mathrm{dl}$ \\
\hline RDWcv & $14.3 \%$ & $13.8 \%$ & $13.4 \%$ \\
\hline RDWsd & $46 f l$ & $45 \mathrm{fl}$ & $48 \mathrm{fl}$ \\
\hline PCT & $11000 / \mathrm{mm} 3$ & $44000 / \mathrm{mm} 3$ & $115000 / \mathrm{mm} 3$ \\
\hline TLC & $400 / \mathrm{mm} 3$ & $1.5 \mathrm{lakh} / \mathrm{mm} 3$ & $61900 / \mathrm{mm} 3$ \\
\hline DLC & $\begin{array}{l}\text { P-23.6 } \\
\text { L-69.4 } \\
M-6.0 \\
\text { E-0.3 } \\
B-0.7\end{array}$ & $\begin{array}{l}95 \% \text { blasts } \\
5 \% \text { lymphocytes }\end{array}$ & $\begin{array}{l}\text { P-90\% } \\
\text { L-08\% } \\
M-01 \% \\
\text { E-01\% }\end{array}$ \\
\hline PS findings & $\begin{array}{l}\text { RBC- normocytic } \\
\text { normochromic RBC } \\
\text { picture.; WBC- leucopenia } \\
\text { seen } \\
\text { TLC < 1000/mm3 } \\
\text { PLT-Decreased } \\
\text { Impression-Pancytopenia }\end{array}$ & $\begin{array}{l}\text { RBC-normocytic normochromic } \\
\text { RBC picture. } \\
\text { WBC-Very high leucocytosis. } \\
\text { Predominant population of } \\
\text { blast cells which show high } \\
\text { N/C ratio, scant agranular } \\
\text { cytoplasm,indented nuclear } \\
\text { membrane and inconscpicuous } \\
\text { nucleoli } \\
\text { PLT - decreased } \\
\text { Impression -acute leukemia }\end{array}$ & $\begin{array}{l}\text { RBC-normocytic normochromic } \\
\text { RBCpicture } \\
\text { WBC- high leucocytosis } \\
\text { Predominant population of } \\
\text { neutrophils seen with moderate } \\
\text { shift to left. } \\
\text { NRBCS + - 10/100wbcs }\end{array}$ \\
\hline
\end{tabular}

Table 2:

\begin{tabular}{|c|c|c|c|}
\hline Case & TLC & DLC & PERIPHERAL SMEAR REPORTING \\
\hline Leukemia & 1.5 lakh/mm3 & $\begin{array}{l}95 \% \text { blasts } \\
5 \% \text { lymphocytes }\end{array}$ & $\begin{array}{l}\text { RBC-normocytic normochromic RBC picture. } \\
\text { WBC-Very high leucocytosis. } \\
\text { Predominant population of blast cells which show high N/C ratio, } \\
\text { scant agranular cytoplasm,indented nuclear membrane and } \\
\text { inconscpicuous nucleoli } \\
\text { PLT - decreased } \\
\text { Impression -acute leukemia }\end{array}$ \\
\hline Pancytopenia & $400 / \mathrm{mm} 3$ & $\begin{array}{l}\text { Pred } \\
\text { lymphocytes }\end{array}$ & $\begin{array}{l}\text { RBC- normocytic normochromic RBC picture. } \\
\text { WBC- leucopenia seen } \\
\text { PLT-Decreased } \\
\text { Impression-Pancytopenia }\end{array}$ \\
\hline L1 & $65000 / \mathrm{mm} 3$ & Blasts + & $\begin{array}{l}\text { RBC- normocytic normochromic RBC picture } \\
\text { WBC-Irregular distribution of cells predominently in base }\end{array}$ \\
\hline L2 & 8000/mm3 & Blasts + & $\begin{array}{l}\text { RBC- normocytic normochromic RBC picture } \\
\text { WBC- Irregular distribution of cells predominently in base }\end{array}$ \\
\hline L3 & $3000 / \mathrm{mm} 3$ & $\begin{array}{l}\text { Few suspicious } \\
\text { cells }+\end{array}$ & $\begin{array}{l}\text { RBC- normocytic normochromic RBC picture } \\
\text { WBC- few cells predominently in base }\end{array}$ \\
\hline L4 & 1500/mm3 & $\begin{array}{l}\text { Few suspicious } \\
\text { cells+ }\end{array}$ & $\begin{array}{l}\text { RBC- normocytic normochromic RBC picture } \\
\text { WBC- Leucopenia with Very few cells in base }\end{array}$ \\
\hline L5 & $<1000 / \mathrm{mm} 3$ & $\begin{array}{l}\text { Pred } \\
\text { lymphocytes }\end{array}$ & $\begin{array}{l}\text { RBC- normocytic normochromic RBC picture } \\
\text { WBC- leucopenia }\end{array}$ \\
\hline
\end{tabular}


Table 3:

\begin{tabular}{|c|c|c|c|}
\hline CASE & TLC & DLC & PERIPHERAL SMEAR REPORTING \\
\hline $\begin{array}{l}\text { Neutrophilic } \\
\text { leucocytosis }\end{array}$ & $61900 / \mathrm{mm} 3$ & $\begin{array}{l}\text { P-90\% } \\
\text { L-08\% } \\
\text { M-01\% } \\
\text { E-01\% } \\
\text { Nrbcs-14/100wbcs }\end{array}$ & $\begin{array}{l}\text { RBC-normocytic normochromic RBC picture; } \\
\text { WBC- high leucocytosis. Predominant population of } \\
\text { neutrophils seen with moderate shift to left. NRBCS } \\
+-10 / 100 \text { wbcs }\end{array}$ \\
\hline Pancytopenia & $400 / \mathrm{mm} 3$ & Pred lymphocytes & $\begin{array}{l}\text { RBC- normocytic normochromic RBC picture.; WBC- } \\
\text { leucopenia seen; PLT-Decreased } \\
\text { Impression-Pancytopenia }\end{array}$ \\
\hline N1 & $30000 / \mathrm{mm} 3$ & $\begin{array}{l}\text { Pred neutrophils. Mature } \\
\text { neutrophils- } 70 \% \text { Band forms } \\
\text { and shift to left cells- } 25 \% \\
\text { NRBCs- } 5 / 100 \text { wbcs }\end{array}$ & $\begin{array}{l}\text { RBC- normocytic normochromic RBC picture.; } \\
\text { WBC-Irregular distribution of cells pedominently } \\
\text { neutrophils and precursors in margins and tail end }\end{array}$ \\
\hline N2 & $5000 / \mathrm{mm} 3$ & $\begin{array}{l}\text { Pred neutrophils. Mature } \\
\text { neutrophils- } 80 \% \text { Band forms } \\
\text { and shift to left cells- } 20 \% \\
\text { NRBCs- } 2 / 100 \text { wbcs }\end{array}$ & $\begin{array}{l}\text { RBC- normocytic normochromic RBC picture. } \\
\text { WBC-Irregular distribution of cells pedominently } \\
\text { neutrophils and precursors in margins and tail end }\end{array}$ \\
\hline N3 & $4000 / \mathrm{mm} 3$ & $\begin{array}{l}\text { Pred neutrophils. Mature } \\
\text { neutrophils- } 90 \% \text { Band forms } \\
\text { and shift to left cells- } 10 \% \\
\text { NRBCs-nil }\end{array}$ & $\begin{array}{l}\text { RBC- normocytic normochromic RBC picture.; WBC- } \\
\text { few neutrophils and band forms seen in tail end }\end{array}$ \\
\hline N4 & $<1000 / \mathrm{mm} 3$ & $\begin{array}{l}\text { Few neutrophils }+ \text { band forms } \\
\text { seen }\end{array}$ & $\begin{array}{l}\text { RBC- normocytic normochromic RBC picture. } \\
\text { WBC-few neutrophils and band forms seen in } \\
\text { margin and tail end }\end{array}$ \\
\hline N5 & $<1000 / \mathrm{mm} 3$ & $\begin{array}{l}\text { Few neutrophils }+ \text { band forms } \\
\text { seen }\end{array}$ & $\begin{array}{l}\text { RBC- normocytic normochromic RBC picture. } \\
\text { WBC-leucopenia }\end{array}$ \\
\hline
\end{tabular}

Table 4:

\begin{tabular}{|c|c|c|c|}
\hline CASE & TLC & DLC & PERIPHERAL SMEAR REPORTING \\
\hline Leukemia & $1.5 \mathrm{lakh} / \mathrm{mm} 3$ & $\begin{array}{l}95 \% \text { BLASTS } \\
5 \% \text { lymphocytes }\end{array}$ & $\begin{array}{l}\text { RBC-normocytic normochromic RBC picture.; WBC- Very high } \\
\text { leucocytosis. Predominant population of blast cells which show high } \\
\text { N/C ratio, scant agranular cytoplasm, indented nuclear membrane } \\
\text { and inconscpicuous nucleoli; PLT - decreased. } \\
\text { Impression - acute leukemia }\end{array}$ \\
\hline Pancytopenia & $400 / \mathrm{mm} 3$ & Pred lymphocytes & $\begin{array}{l}\text { RBC- normocytic normochromic RBC picture.; WBC- leucopenia } \\
\text { seen; PLT-Decreased. Impression-Pancytopenia }\end{array}$ \\
\hline $\mathrm{LA}+$ & $90000 / \mathrm{mm} 3$ & BLASTS+ & $\begin{array}{l}\text { RBC-normocytic normochromic RBC picture; WBC-Irregular } \\
\text { distribution of cells mainly in base and margins. High leucocytosis } \\
\text { predominant population of blasts }\end{array}$ \\
\hline LB+ & 1lakh/mm3 & BLASTS+ & $\begin{array}{l}\text { RBC-normocytic normochromic RBC picture; WBC- Irregular } \\
\text { distribution of cells mainly in base. High leucocytosis predominant } \\
\text { population of blasts }\end{array}$ \\
\hline $\mathrm{LC}+$ & 60000/mm3 & BLASTS+ & $\begin{array}{l}\text { RBC-normocytic normochromic RBC picture; WBC- Irregular } \\
\text { distribution of cells mainly in base. High leucocytosis predominant } \\
\text { population of blasts }\end{array}$ \\
\hline LD+ & $80000 / \mathrm{mm} 3$ & BLASTS+ & $\begin{array}{l}\text { RBC-normocytic normochromic RBC picture; WBC- Irregular } \\
\text { distribution of cells mainly in base and margins. High leucocytosis } \\
\text { predominant population of blasts }\end{array}$ \\
\hline LE+ & $55000 / \mathrm{mm} 3$ & BLASTS+ & $\begin{array}{l}\text { RBC-normocytic normochromic RBC picture; WBC- Irregular } \\
\text { distribution of cells mainly in base. High leucocytosis predominant } \\
\text { population of blasts }\end{array}$ \\
\hline
\end{tabular}


Table 5:

\begin{tabular}{|c|c|c|c|}
\hline CASE & TLC & DLC & PERIPHERAL SMEAR REPORTING \\
\hline $\begin{array}{l}\text { Neutrophilic } \\
\text { leucocytosis }\end{array}$ & $61900 / \mathrm{mm} 3$ & $\begin{array}{l}\text { P-90\%; L-08\%; M-01\%; E-01\%; } \\
\text { NRBSs-14/100wbcs }\end{array}$ & $\begin{array}{l}\text { RBC-normocytic normochromic RBC picture; } \\
\text { WBC- high leucocytosis. Predominant population of } \\
\text { neutrophils seen with moderate shift to left. NRBCS } \\
+-10 / 100 \text { wbcs. }\end{array}$ \\
\hline Pancytopenia & $400 / \mathrm{mm} 3$ & Predominantly lymphocytes & $\begin{array}{l}\text { RBC- normocytic normochromic RBC picture.; WBC- } \\
\text { leucopenia seen. ; PLT-Decreased. Impression- } \\
\text { Pancytopenia }\end{array}$ \\
\hline $\mathrm{NA}+$ & $30000 / \mathrm{mm} 3$ & $\begin{array}{l}\text { Pred neutrophils. P-92\%; } \\
\text { L-08\%; NRBCs-6/100wbcs }\end{array}$ & $\begin{array}{l}\text { RBC- normocytic normochromic RBC picture. ; WBC- } \\
\text { Leucocytosis seen with predominant population of } \\
\text { neutrophils. }\end{array}$ \\
\hline NB+ & $25000 / \mathrm{mm} 3$ & $\begin{array}{l}\text { Pred neutrophils. P-85\%; } \\
\text { L-14\%; E-1\%; NRBC- } \\
\text { 10/100wbcs }\end{array}$ & $\begin{array}{l}\text { RBC- normocytic normochromic RBC picture.; WBC- } \\
\text { Leucocytosis seen with predominant population of } \\
\text { neutrophils }\end{array}$ \\
\hline $\mathrm{NC}+$ & $20000 / \mathrm{mm} 3$ & $\begin{array}{l}\text { Pred neutrophils. P-95\%; } \\
\text { L-55\%; Nrbcs-2/100wbcs }\end{array}$ & $\begin{array}{l}\text { RBC- normocytic normochromic RBC picture.; WBC- } \\
\text { Leucocytosis seen with predominant population of } \\
\text { neutrophils }\end{array}$ \\
\hline ND+ & $32000 / \mathrm{mm} 3$ & $\begin{array}{l}\text { Pred neutrophils. P-90\%; } \\
\text { L-10\%; Nrbcs-nil }\end{array}$ & $\begin{array}{l}\text { RBC- normocytic normochromic RBC picture.; WBC- } \\
\text { Leucocytosis seen with predominant population of } \\
\text { neutrophils }\end{array}$ \\
\hline $\mathrm{NE}+$ & $18000 / \mathrm{mm} 3$ & $\begin{array}{l}\text { Pred neutrophils. P-91\%; } \\
\text { L-09\%; Nrbcs-1/100wbcs }\end{array}$ & $\begin{array}{l}\text { RBC- normocytic normochromic RBC picture. ;WBC- } \\
\text { Leucocytosis seen with predominant population of } \\
\text { neutrophils }\end{array}$ \\
\hline
\end{tabular}

\section{TAIL END}

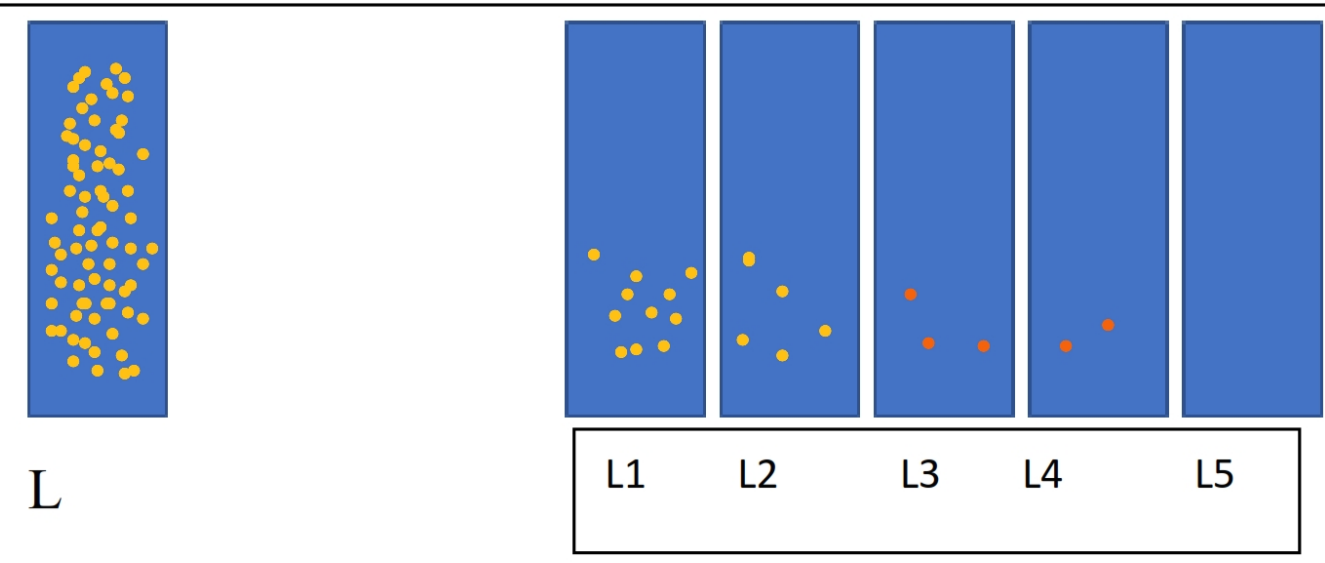

HEAD END

Carried over cells with malignant features.

- Carried over cells with poorly maintained features suspicious for malignant cells

Fig. 1 : 


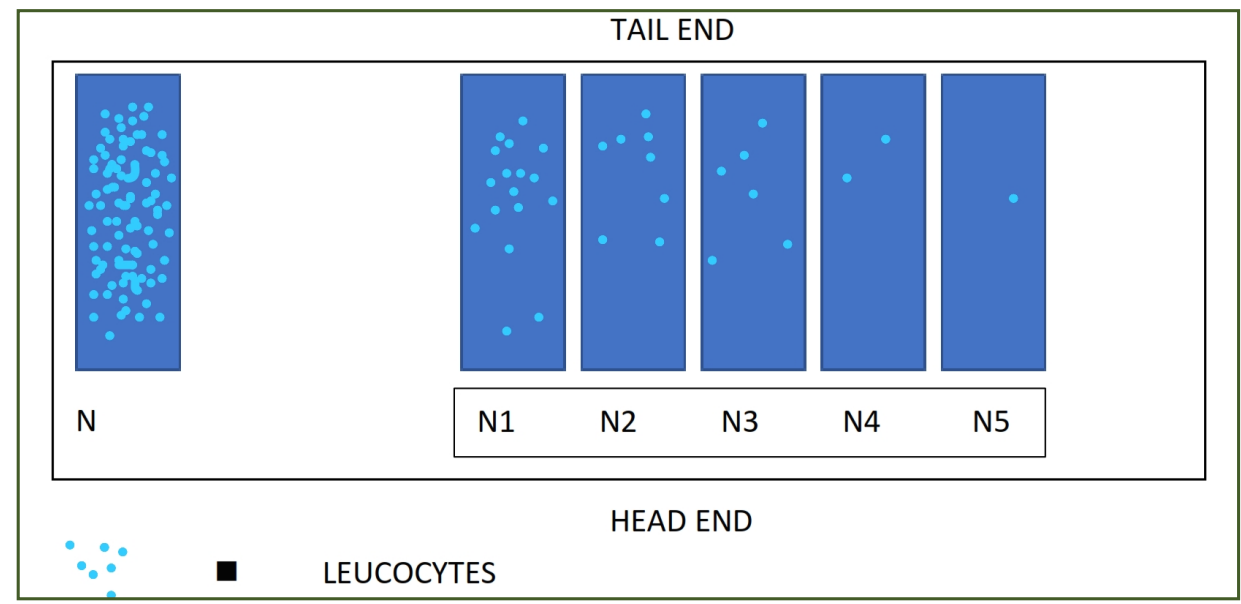

Fig. 2:

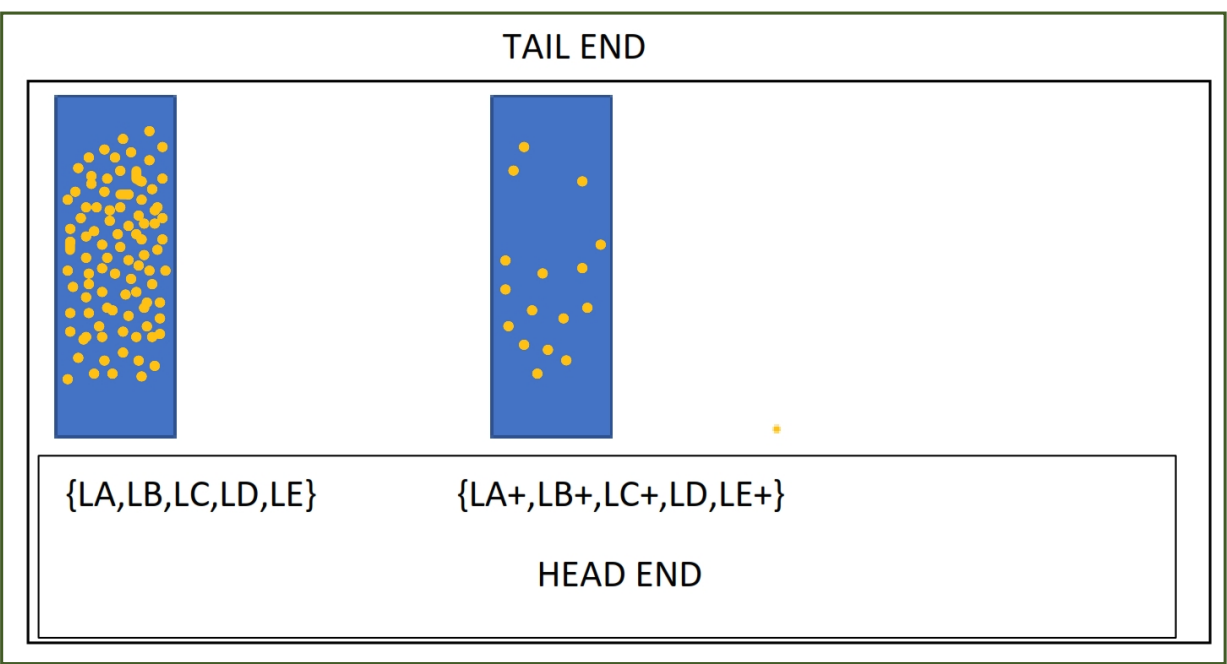

Fig. 3 : Common representational image LA and LA + to LF and LF+

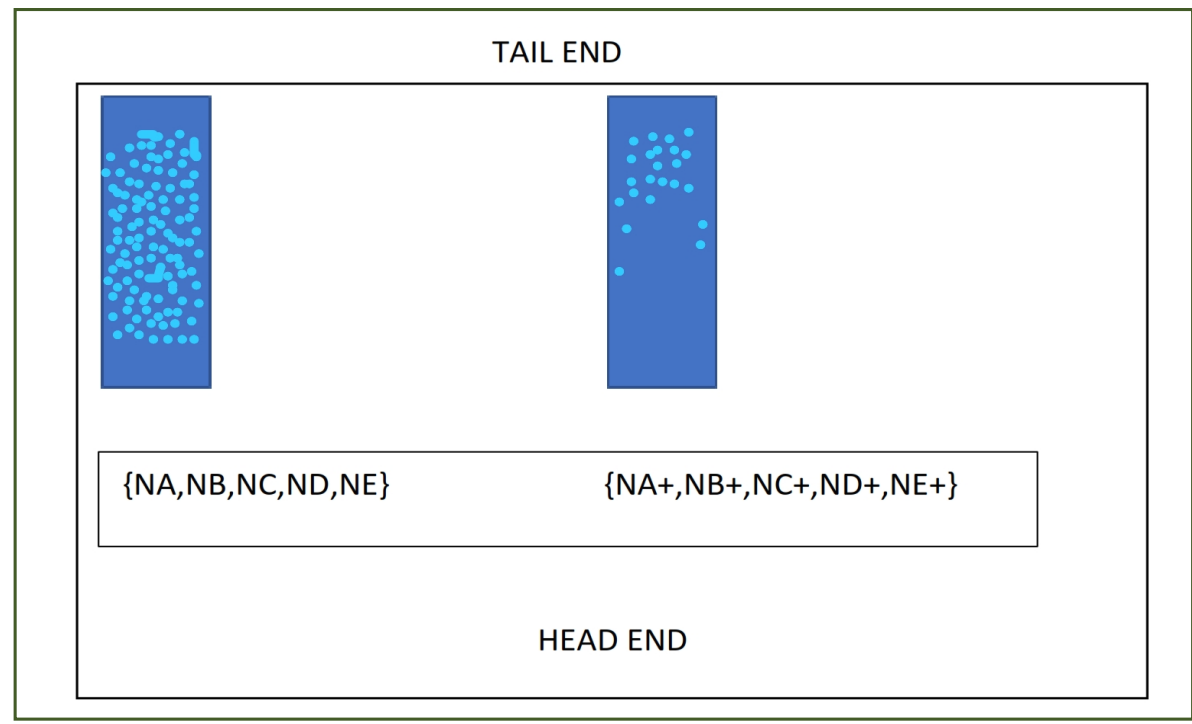

Fig. 4 : Common representational image for NA and NA = to NE and NE+ 


\section{Conclusion}

There was clear carry over of cells to the successive smears by use of same spreader. Carry over was more significant in the successive 3 smears in order. There was irregular distribution of carried cells. In case of malignancy carried over cells were more commonly distributed in head of the smear and in case of neutrophilic leucocytosis carried over cells were more commonly found in tail end and margins of the smear.

Caution need to be used in laboratories with high case load where multiple smears need to be prepared and time constraint is a limiting factor. Use of advanced coulters can help in correlation of cells counts and typing instead of only depending on smears for cells counts and reporting. Collecting clinical details of the patient is an important step which is indispensable.

\section{Acknowledgements}

Faculty, friends, and family members have helped me to complete this study. I would like to express my gratitude to these individuals for their support and assistance. I would love to express my gratitude to all the staff of central collection center of Safdarjung hospital for their support and help.

\section{Reference}

1. Vajpayee N, Graham SS, Sylva Bem. Basic Examination of Blood and Bone Marrow. In: McPherson RA, Pincus MR. Henry's Clinical Diagnosis and Management by Laboratory Methods. 21st ed. Philadelphia: Elsevier Saunders; 2007.

2. Bain BJ. Diagnosis from the blood Smear. N Engl J Med. 2005;353:498-507

3. Levine MS, Levine DS. Automatic blood film preparation method.1998

4. Ryan DH. Automated analysis of blood cells. In: Hoffman R, Benz EJ, Shattil SJ, Furie B, Cohen HJ, Silberstein LE, editors. Hematology: basic principles and practice. 2nd ed. New York: Churchill Livingstone; 1995. pp. 2223-2235.

5. Buttarello M, Plebani M. Automated blood cell counts: state of the art. Am J Clin Pathol. 2008;130(1):104-116

6. Barnes PW, McFadden SL, Machin SJ, Simson E, International Consensus Group for Hematology The international consensus group for hematology review: suggested criteria for action following automated $\mathrm{CBC}$ and WBC differential analysis. Lab Hematol. 2005;11(2):83-90

*Corresponding author:

Sumanashree Mallappa “ Malayashree Nilaya” 2 cross, 1 B main Nagarbhavi village, Bangalore - 560072 India hone: +91 9990476487

Email: simplysumana@yahoo.co.in 